LINK Working Paper Series

WP 02-09

Conceptualising Collaborative

Processes in University

Research Centres

Angelos Alexopoulos

Brian Harney

Kathy Monks

Finian Buckley

Teresa Hogan

The Learning, Innovation and Knowledge Research Centre

DCU Business School

Dublin City University

Glasnevin

Dublin 9

Ireland

link.dcu.ie 


\section{Acknowledgements}

We would like to acknowledge funding provided by Higher Education Authority (HEA) under the Programme for Research in Third Level Institutions (PRTLI) Cycle 4 as part of the Irish Social Sciences Platform (ISSP) research on Knowledge Economy and Society.

THE LEARNING, INNOVATION AND KNOWLEDGE (LINK) RESEARCH CENTRE WORKING PAPER SERIES http://www.link.dcu.ie/publications/workingpaperseries/

(C) 2009, Conceptualising Collaborative Processes in University Research Centres, Angelos Alexopoulos, Brian Harney, Kathy Monks, Finian Buckley and Teresa Hogan.

Authors are responsible for the accuracy of citations, quotations, diagrams, tables and maps.

The views expressed here do not necessarily reflect those of Learning, Innovation and Knowledge (LInK) Research Centre.

All or part of this work may be reproduced for the purposes of study, research, criticism or review provided that the author and the Learning, Innovation and Knowledge (LInK) Research Centre are fully acknowledged.
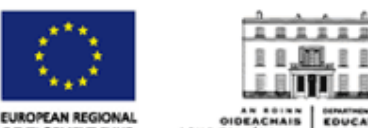


\title{
Conceptualising Collaborative Processes in University Research Centres
}

\author{
$\bullet \bullet \bullet \bullet \bullet \bullet \bullet \bullet \bullet \bullet \bullet \bullet \bullet \bullet \bullet \bullet \bullet \bullet \bullet$ \\ Angelos Alexopoulos \\ BRIAN HARNEY \\ KATHY MONKS \\ FINIAN BUCKLEY \\ TERESA HOGAN
}

\begin{abstract}
In the context of a knowledge-based agenda understanding the dynamics of the collaborative process between universities and industry becomes critical. This paper develops an analytical framework for examining the processes underpinning the collaborative capabilities of University Research Centres (URCs). Drawing on the lens of collaborative communities, this multi-level framework provides a useful basis for understanding in more detail the unique motives, relational dynamics and negotiated orders informing and shaping the formation and sustenance of research collaboration in URCs. Implications for the management of scientific and technical (S\&T) human capital are discussed.
\end{abstract}

Key Words: Research collaboration, innovation, university research centres, microfoundations. 


\section{INTRODUCTION}

It is widely acknowledged by scholars, industry analysts and policy makers that universities and their research activities serve as catalysts in fostering the development of industrial innovation within an increasingly knowledge-based economy and society (Beesley, 2003; Salter \& Martin, 2001). Previous studies have shown that academic research accounts for at least $10 \%$ of the new products and processes introduced by firms (Beise \& Stahl, 1999; Mansfield, 1991, , 1998). In particular, viewed through the lens of the 'triple-helix' paradigm (Etzkowitz \& Leydesdorff, 1997), universities and other higher education institutions (HEI) are now considered to play an enlarged strategic role not only in the creation but also in the transfer and capitalisation of scientific knowledge by repositioning themselves in collaborative arrangements with industry partners (Etzkowitz, Webster, Gebhardt, \& Terra, 2000; Hernes \& Martin, 2000). In the UK, for example, Lambert (2003: 3) has termed this trend as one of 'casting off their ivory tower image'. The establishment of linkages between industry and science also features prominently in the Irish government's Strategy for Science, Technology and Innovation 2006-2013 (SSTI 2006-2013). One of its key aims is to "ensure more effective commercialisation of the ideas and know-how being generated in our universities and public research institutions, and to forge new partnerships between these institutions and enterprise' (DETE, 2006).

In this paper, we place emphasis on University Research Centres (URCs) as a key exemplar on the frontier of campus-industry interactions, thereby bringing university research activities and outcomes into sharper focus. Combining 'firm-like' qualities with the quest for academic excellence (Bozeman \& Boardman, 2003; Etzkowitz, 2003), URCs provide an ideal setting for exploring the dynamics of how research collaboration and commercialisation activities are organised and how key tensions are played out in practice.

More specifically, drawing upon recent advances in the knowledge-based view of the firm, we suggest that URCs may reflect many characteristics inherent to what has been described as 'collaborative communities' (Adler, Kwon, \& Heckscher, 2008; Heckscher \& Adler, 2006). Essentially, such a view not only acknowledges that the 'singular single feature that all university centers, broadly defined, have in common is the intention to foster collaboration between researchers' (Boardman \& Corley, 2008) but it also recognises the limits of market or hierarchy based mechanisms for coordinating collaborative relations with both internal and external partners (Adler \& Heckscher, 2006). In addition, we go a step further to examine some key microfoundations or emergent processes (Felin \& Hesterly, 2007; Foss, 2007) underpinning the formation and sustenance of collaborative relations and to highlight their implications for the design and implementation of leadership and management practices and processes that fit the requirements of high performing URCs.

The overall contribution of this paper thus lies in developing an analytical framework which depicts cross-level interactions of organisational and individual

THE LEARNING, INNOVATION AND KNOWLEDGE (LINK) RESEARCH CENTRE WORKING PAPER SERIES WP 02-09 
factors shaping university research activities and outcomes. This framework also provides a useful basis for examining key interventions for motivating and managing researchers, while also appreciating the factors shaping individual research efforts and subjective experiences, including their commitment to their organisation and profession, and their career progression opportunities.

The paper is organised into three sections as follows. The first section provides an overview of the defining characteristics of URCs and the distinct nature of scientific and technical (S\&T) human capital therein. The second section introduces the concept of collaborative community and highlights its applicability to the context of URCs. In the third section we focus on the motives, relational dynamics and negotiated orders that shape research collaboration. Our proposed analytical framework is then introduced followed by a discussion of its implications for the management of S\&T human capital towards advancing the collaboration capability of URCs.

\section{UNIVERSITY RESEARCH CENTRES: AN OVERVIEW}

\section{URCs: Definitions, Taxonomies and Challenges}

URCs and institutes, or what are commonly referred to in the literature as 'organized research units' (ORUs) (Geiger, 1990; Hays, 1991), comprise an extremely diverse array of academic organisational entities. The nature, number and characteristics of URCs vary considerably across universities. In particular, URCs vary enormously across a number of dimensions, some of which include: (1) size of external support and research staff, (2) the proportion of faculty versus professional staff researchers, (3) level of separation from academic departments, (4) level of integration with the university, (5) level of interdisciplinary and multidisciplinary focus, and (6) relative emphasis on applied research (Stahler \& Tash, 1994). In addition, URCs are a unique form of university organisation in several respects: (1) they are interdisciplinary, involving faculty members from various academic departments (2) they are boundary spanners, facilitating a flow of information and other resources across the university's boundary, and (3) they are temporary organizations at least compared to university departments, and provide a degree of flexibility in an otherwise stable university structure (Rogers et al., 1999).

Given this range of organisational characteristics, it is not surprising that there are difficulties in defining precisely what constitutes a URC. It is, however, useful to provide a working definition that helps distinguish URCs from other types of university research entities, particularly academic departments or research teams therein. Accordingly, a URC can be defined as a 'formal organizational entity within a university that exists chiefly to serve a research mission, is set apart from the departmental organization, and includes researchers from more than one department (or line management unit)' (Bozeman \& Boardman, 2003: 17). Building on this definition, Bozeman \& Boardman (2003) provide a rudimentary taxonomy of URCs

THE LEARNING, INNOVATION AND KNOWLEDGE (LINK) RESEARCH CENTRE WORKING PAPER SERIES WP 02-09 
along a number of variables including horizontal and external relations, extra-research activities and research problem focus (see Table 1).

Insert Table 1 about here

Notwithstanding the variation in the types of URCs shown in Table 1, a key characteristic commonly shared by URCs is the intention to foster collaboration between researchers' (Boardman \& Corley, 2008: 901). The composition and direction of these collaborations will of course vary depending on the strategic goals and research problem focus of the particular centre. For example, some will be across disciplines and departments; others across universities, industry and within and across countries. The key challenge, however, as Boardman \& Corley (2008: 901) put it, is how URCs 'synergistically as a collaborative unit possess the scientific capacity...to achieve these goals'.

Whereas the term 'human capital' is generally used within the business literature to describe human resource capabilities within knowledge-intensive firms (KIFs), the term 'S\&T [scientific and technical] human capital' is more likely to be found in descriptions of human resource capabilities in URCs. S\&T capital has been defined as 'the sum of researchers' professional network ties and their technical skills and resources' (Bozeman, Dietz, \& Gaughan, 2001). Thus, it is proposed that when scientists affiliate with a research centre, 'their prospective professional networks and resource caches are enhanced by other scientists participating in the center (Dietz \& Bozeman, 2005)' especially when these 'other scientists have different disciplinary backgrounds and/or come from different organizations and sectors' (Boardman \& Corley, 2008: 903). Boardman \& Corley (2008: 903) propose that URCs are essentially 'strategic exercises in S\&T human capital enhancement...to further a field of research and development'.

\section{Collaboration Capability of URCs}

The concept of S\&T human capital can also be used to explain how URCs' participants and stakeholders affect researchers' behaviour. As individuals, scientists cannot be expected to have the S\&T human capital to achieve the scientific and technical goals of the centre. They must, therefore, collaborate with one another to achieve these goals. The ways in which such collaboration might be measured varies with some studies focusing on authorship (Katz \& Martin, 1997) and others on time allocation (Boardman et al., 2008; Bozeman \& Corley, 2004).

Studies of the impact of organisational and individual characteristics on research activity have focused on a variety of factors. These include inputs such as research expenditure, the number of faculty, the prestige of the institution; and outputs such as the number of patents and licensing agreements. However, Boardman \& Corley (2008) suggest that very few of these studies have explained the effect of organizational attributes on individual scientists' behaviours. Their study of a national

THE LEARNING, INNOVATION AND KNOWLEDGE (LINK) RESEARCH CENTRE WORKING PAPER SERIES WP 02-09

http://www.link.dcu.ie/publications/workingpaperseries/

(c) 2009, LInK, Angelos Alexopoulos, Brian Harney, Kathy Monks, Finian Buckley and Teresa Hogan Contact: angelos.alexopoulos@dcu.ie 
level sample of research universities in the USA included 1647 researchers and suggests that URCs alter the behaviours of researchers by facilitating research collaboration. In addition, centres that had industry links increased the time spent by researchers on collaboration outside the immediate work group. They found that centre managers are faced with specific challenges in that they cannot necessarily control the range of factors that affect the behaviours of individual researchers. In particular, they have no control over the incentive structures that exist within academic departments.

In addition, studies have shown that collaboration may have its downside. For example, research undertaken among 443 academic scientists affiliated to URCs in the USA found that it was somewhat difficult to evaluate the overall impact of collaboration (Lee \& Bozeman, 2005). The 'simple' question posed in Lee \& Bozeman's (2005) study - the extent to which scientists' collaborations affect their publishing productivity - provided answers that proved complex to analyse. In particular, it was found that 'when publishing productivity is measured by "normal count' (a scientist' total number of publications), collaboration is a strong predictor of publishing productivity'. But when publishing productivity was measured by 'fractional count' (dividing credit by the number of co-authors), collaboration and publishing productivity are not significantly related, at least not in a model controlling for moderating variables' (ibid: 693). Based on these results, they suggest the need for more research on 'the impact of collaboration, in all its forms, on research productivity, in all its meanings' (ibid.).

\section{UNIVERSITY RESEARCH CENTRES AS COLLABORATIVE COMMUNITIES}

A core assumption of the knowledge-based view of the firm suggests that organisations are better suited than markets for gathering and disseminating knowledge (Kogut \& Zander, 1992; Staples, Greenaway, \& McKeen, 2001). The underlying argument is that, in a knowledge-based economy, the core advantage of corporate organisations over markets does not lie in their ability to reduce transaction costs through hierarchical coordination or market price mechanisms (Williamson, 1985). Instead, it is inextricably linked to the possession of 'unique advantages for governing certain kinds of economic activities through a logic that is very different from that of a market' (Ghoshal \& Moran, 1996). This logic is reflected in an emerging theorising of the firm as a social, collaborative community (Adler, 2001; Adler et al., 2008; Brown \& Duguid, 2001; Heckscher et al., 2006; Inagami \& Whittaker, 2005). We suggest that collaboration activities in URCs can be fruitfully analysed through the lens of this emerging mode of theorising.

\section{Collaborative Community}

The notion of collaborative community refers to a distinct principle of social organisation that contrasts radically with that of markets or hierarchies in regard to its

THE LEARNING, INNOVATION AND KNOWLEDGE (LINK) RESEARCH CENTRE WORKING PAPER SERIES WP 02-09 
fundamental coordination mechanism. In particular, markets rely on prices to coordinate competing economic actors, whereas hierarchies rely on authority and control to coordinate dependent activities among employees whose roles are prescribed based on a detailed division of labour. Collaborative communities rely heavily on trust and, more widely, on the structure and quality of social relations among its members to create, share, combine and integrate knowledge (Adler, 2001; Inagami \& Whittaker, 2005; Adler \& Heckscher, 2006). In turn, these processes, particularly knowledge combination and integration, are viewed as constituent parts of the innovation process (Schumpeter, 1934[1962]).

As knowledge generation and sharing become increasingly the main sources of value creation for the contemporary firm (Kang, Morris, \& Snell, 2007) and the successful management of knowledge emerges as its key performance determinant, organising forms that rely primarily either on hierarchies (i.e., Gemeinschaft) or markets (i.e., Gesellschaft) are limited in their ability to coordinate knowledge-based work (Adler \& Heckscher, 2006). Instead, collaborative corporate community represents an alternative organising template, which serves as an essential precondition for the effective management of knowledge (Adler, 2001) and consequently for organisational learning (March, 1991).

In the collaborative community-based model, the key requirement for effective coordination of complex knowledge processes is related less to the extent to which individuals feel morally obliged to contribute their knowledge to the organisation as such, than to the extent to which there is a shared understanding between individuals across functions that makes 'possible a process of bestowing of tacit knowledge by the individual' (von Krogh, Ichijo, \& Nonaka, 2001). The notion of 'understanding' takes here the meaning of 'sympathy under uncertainty' (DiMaggio, 1992), while the notion of 'knowledge bestowing' resembles the concept of 'taking care' (Appley \& Winder, 1977; Ciborra, 1996; von Krogh, 2003). Both notions are underpinned by a distinct type of trust fuelled mainly by mutual contribution, concern, honesty, tolerance and collegiality (Adler \& Heckscher, 2006). This type of trust, in turn, fits the interactive social character and the socioeconomic base of the modern organisation (Maccoby, 2006).

\section{(Re)Conceptualising URCs as Collaborative Communities}

Arguably, research exploring URCs needs to engage with theoretical perspectives that help accommodate its unique features, its mode of operation and its research motives. Here it may be useful to suggest that URCs reflect many characteristics inherent to the notion of collaborative community. We argue that this mode of theorising recognises the limits of pure market-based mechanisms for gathering and disseminating knowledge. At the same time it also recognises the limits inherent to traditional hierarchical and bureaucratic ways of organising at a university level. At the risk of oversimplifying issues Table 2 provides a summary of the contrasts between the three 
principles of social organisation and locates URCs as a distinct type of collaborative community.

Insert Table 2 about here

Understanding URCs as a qualitatively distinct form of collaborative community means appreciating that effective co-ordination of complex tasks is founded upon notions of trust, professionalism, collegiality and shared understandings between individuals across functions. This logic fits the socially interactive and process-based nature of research and knowledge generation activities. However, it is also important to appreciate that the three principles outlined in Table 2 represent ideal types and contrasting extremes, with actual organisations likely to reflect a mix of rationales and perhaps only reflecting a dominant tendency in one direction. Nonetheless, there is a sense that in a domain where knowledge generation and sharing become the main sources of value creation organising forms that rely primarily either on hierarchies (i.e. Gemeinschaft) or markets (i.e. Gesellschaft) are limited in their ability to coordinate complex, highly interdependent, and non-routine activities (Adler \& Heckscher, 2006). This is due to the axiom that a collaborative community is governed by an ethic of interdependent contribution to a shared purpose and the success of others. In this sense, value creation is, to a large extent, contingent upon the extent to which employees 'believe that others have contributions to make towards this shared creation' (Adler \& Heckscher, 2006: 21).

Here perhaps it is pertinent to evoke McGrath's (2005: 559) observation in relation to medieval monastic communities: 'the monks did not create a community but were one'. McGrath (2005) provides an interesting perspective on the notion of the modernity of the knowledge work concept by comparing the structure and functioning of contemporary knowledge-intensive organisations with that of early Irish monastic communities. As the Golden Age of Irish monasticism can be dated back to the $7^{\text {th }}$ and early $8^{\text {th }}$ centuries, McGrath's analysis raises interesting issues about the ways in which the nature of contemporary KIFs, including URCs, might be understood. Table 3 sets out what he identifies as central features of both forms (McGrath, 2005).

Insert Table 3 about here

Essentially, a view of URCs as collaborative communities acknowledges the social embeddedness of work organisations and, therefore, the role of social relations in shaping exchange activities among their members (Granovetter, 1985). As such, collaborative communities are 'constructed by individuals whose action is both facilitated and constrained by the structure and resources available in social networks in which they are embedded' (Granovetter, 1992). Thus, one of the key challenges for URCs under pressure for transparency and procedural legitimacy from partners and

THE LEARNING, INNOVATION AND KNOWLEDGE (LINK) RESEARCH CENTRE WORKING PAPER SERIES WP 02-09

http://www.link.dcu.ie/publications/workingpaperseries/

(c) 2009, LInK, Angelos Alexopoulos, Brian Harney, Kathy Monks, Finian Buckley and Teresa Hogan Contact: angelos.alexopoulos@dcu.ie 
university bodies alike is in creating an infrastructure which fosters and sustains ongoing, mutually beneficial exchange relationships and the engagement of their members in collaborative activities with both internal and external partners (Adler et al., 2008). In their overview (Markman, Siegel, \& Wright, 2008) similarly point to the importance of examining the 'paradox' of how innovation can be stimulated while at the same time its benefits are simultaneously realised.

Recent empirical research suggests that such a transition towards an entrepreneurial archetype in which commercialisation becomes the norm rather than the exception is, however, far from frictionless (Owen-Smith, 2003; Stern, 2004). Probably the biggest challenge universities are faced with concerns the development of an ambidextrous capability in their efforts towards achieving academic excellence on one hand and promoting commercialisation activities on the other (Ambos, Makela, Birkinshaw, \& D'Este, 2008). However, while documenting how universities have evolved to become ambidextrous in their ability to retain traditional trajectories while also moving to systematically interact with industry partners provides a useful foundation for understanding university core capabilities, a sole focus on macro-level interactions is limited for it ignores what Markman et al. (2008: 1401) recently described as the 'most vexing, yet under-researched predicaments research institutions encounter, despite their best efforts to advance commercialization'. Indeed, with few exceptions (Sousa \& Hendriks, 2008), previous research has fallen short in providing in-depth insights into the organisational and management challenges and requirements for developing such capabilities (Markman et al., 2008). In sum, there is not much known about the underlying processes or microfoundations driving collaborative innovation in a university research setting (cf. Foss, 2007).

\section{COLLABORATIVE INNOVATION IN URCs: IN SEARCH OF MICROFOUNDATIONS}

An organisation's ability to innovate, that is to invent and implement (i.e., accrue value from) new ideas (Schumpeter, 1934[1962]), is dependent upon the creation and transfer of valuable knowledge within and across its boundaries (Argote, McEvily, \& Reagans, 2003). However, new ideas and insights do not occur in isolation; they are the outcome of research collaboration (Eaton, 1951). This can be defined as 'working closely with others to produce new scientific knowledge or technology' (Bozeman \& Corley, 2004: 605). This is particularly the case in URCs where individuals and teams of scientists and researchers from within and across disciplines come together to exchange and combine their knowledge, skills and perspectives in order to solve problems of increased complexity. Scientific collaboration, as manifested for example in Big Science laboratories such as CERN (Conseil Européen pour la Recherche Nucléaire) in Geneva (Knorr Cetina, 1999), remains one of the most frequently invoked examples of successful inter-disciplinary collaboration (Cronin, 1995). In this section, and consistent with the collaborative community mode of theorising, we

THE LEARNING, INNOVATION AND KNOWLEDGE (LINK) RESEARCH CENTRE WORKING PAPER SERIES WP 02-09

http://www.link.dcu.ie/publications/workingpaperseries/

(c) 2009, LInK, Angelos Alexopoulos, Brian Harney, Kathy Monks, Finian Buckley and Teresa Hogan

Contact: angelos.alexopoulos@dcu.ie 
consider some of the motives, relational dynamics, and negotiated orders that inform and shape research collaboration in URCs.

\section{Motives for Research Collaboration}

In an early account of the advantages and challenges of scientific team-based research, Eaton (1951: 708) identified four main reasons as to why researchers choose to collaborate. In particular, collaboration is seen as a means of: (1) dealing with the increasing complexity of the knowledge base; (2) enhancing intellectual stimulation, knowledge sharing and constructive criticism; (3) facilitating the integration of theoretical assumptions across different disciplines; and (4) promoting division of labour in situations where a single researcher may be handicapped. Later research on the origins and development of scientific collaboration in European science (Beaver, 2001; Beaver \& Rosen, 1978; Beaver \& Rosen, 1979a, , 1979b) has identified a variety of motives for collaboration. These are summarised in Table 4.

Insert Table 4 about here

Arguably, collaborative intent is also expected tacitly or explicitly by foundations, government agencies and other national or international research funding bodies. Indeed, in many cases collaboration stands as a sine qua non of grant awards (e.g., EU's Seventh Framework Programme for Research and Technological Development). Success in attracting research funds is therefore inextricably linked to the ability to form inter-disciplinary, multi-institutional and, in cases, cross-national teams. Increasingly, as Cronin (1995) points out, building collaborative relations may be the only way in which researchers can ensure access to the physical, intellectual and symbolic resources to support their scientific endeavours.

\section{Relational Dynamics of Research Collaboration}

Notwithstanding the role of socio-cognitive, institutional and environmental factors in governing collaboration, scholars suggest that collaborations often emerge from preexisting informal relations between colleagues comprising the 'invisible college' (Price \& Beaver, 1966). Prior research has long highlighted the importance of informal networks of exchange for the likelihood of collaboration (Crane, 1970; Garvey \& Griffith, 1972). Less agreement, however, exists with regard to whether the primary motive for collaboration is found in the expected benefits of economic or social exchange relations (Edge, 1979; Hagstrom, 1965; Price, 1963). On one hand, as Price (1963: 160) maintained, collaboration - in the form of co-authorship - 'arises mode from economic than from intellectual dependence'. On the other hand, when collaboration is initiated informally, "possible partners may approach it very gingerly, even as boys and girls do not, at the first meeting, suggest the possibility of romantic collaboration, although this may be very much on their minds' (Hagstrom, 1965: 114).

THE LEARNING, INNOVATION AND KNOWLEDGE (LINK) RESEARCH CENTRE WORKING PAPER SERIES WP 02-09 
Consistent with the collaborative community mode of theorising, we suggest that researchers' collaborative efforts are governed both by an ethic of interdependent contribution to a shared purpose and the success of others, and by pragmatic business considerations (Adler \& Heckscher, 2006). While the first governing mechanism points to the role of trust, commitment, communication, time and territory as the building blocks of collaborative capability (Blomqvist \& Levy, 2006; Miles, Snow, \& Miles, 2000), the second one highlights the fact that collaboration can also provide substantial returns for individuals in terms of career progression and recognition in the professional community (Beaver et al., 1978; Cronin, 1995). In this regard, research collaboration can be understood better as a strategic choice (Katz \& Martin, 1997). Boardman \& Corley (2004) argue that while such an approach points to the inherent difficulties in disentangling the human capital from the social capital endowments that comprise what has been described as S\&T human capital (Bozeman et al., 2001), it nevertheless suggests that 'many of the factors governing individual scientists' collaboration choices remain very much within the control of the individual, especially when the researcher works in an academic institution' (Boardman \& Corley, 2004: 600).

\section{(Re)Negotiated Orders of Research Collaboration}

Based on a sample of 451 scientists and engineers at academic research centres in the US, Boardman \& Corley's (2004) study indicates how various collaboration strategies employed by individual researchers, such as the 'mentor', 'tactician' and 'cosmopolitan' strategies, are associated distinctly with S\&T human capital endowments, including gender, tenure and grants. In particular, it was found that researchers pursuing a mentor strategy were more likely to be tenured, work with graduate students and junior faculty, collaborate with women, and have a favourable orientation to industry work. However, grants were not significantly associated with the mentor strategy. In contrast, it was found that males were more likely to be tacticians as are researchers with larger grants. Boardman \& Corley (2004: 614) conclude by noting that

[t]he inclusion of early career and underrepresented scientists in funded projects does not insure that that they will have the collaboration opportunities and it does not ensure that the collaboration opportunities afforded will help them significantly to enhance their S\&T human capital.

The findings of Boardman \& Corley's (2004) study point to the need for a greater understanding of research collaboration by taking a closer look at its implications for the appropriation of S\&T human capital as well as the role of leadership and management practices therein. This is particularly important in the light of increased managerial pressures in public university research institutes (Cohen, Duberley, \& McAuley, 1999) and their impact on the 'renegotiation of the professional and personal interests of researchers' (Sousa \& Hendriks, 2008: 812)

THE LEARNING, INNOVATION AND KNOWLEDGE (LINK) RESEARCH CENTRE WORKING PAPER SERIES WP 02-09 
and, subsequently, on their stance to commitment. To note that under the collaborative community perspective 'commitments and their enforcement are neither part of the informal culture nor automatically linked to hierarchy: they must be deliberately agreed to' (Adler \& Heckscher, 2006: 53). There is, however, little understanding of how 'democratic teamwork' (Eaton, 1951) translates into actual research management practice, which thereby engenders the development of S\&T human capital.

\section{A Framework for Understanding Collaboration in URCs}

Even though university research is tasked with 'creating the future' (Brint, 2005) it remains the case that we have little knowledge on the actual practices and processes that may facilitate universities in realising this promise. The theoretical lens of collaborative communities opens up one route for empirical efforts to offer better insights into how URCs are managed and key tensions are negotiated. To date work on the role and potential of URCs in the innovative process has suffered from 'explanatory naivety' in simplistically linking attributes such as the presence/experience of supportive technology transfer infrastructure directly to innovative capabilities. As Foss (2007) notes, the difficulty with such approaches is that explanation takes place solely on the collective level. This tendency is indicated at the macro-level in Figure 1 below.

Insert Figure 1 about here

In contrast Figure 1 follows a more process-based orientation and includes the meso- and micro-level interactions which shape collaborative innovation. This includes examining the key interventions for motivating and managing researchers (i.e., leadership and management processes), while also appreciating the factors shaping researchers' abilities, motivation and opportunities, including their previous training, commitment to their organisation and profession, and career trajectory opportunities. Thus, following the classic work of Burns \& Stalker (1961), behaviour is perceived as a medium of the constant interplay and mutual redefinition of individual abilities, interests and beliefs, and social institutions. Research on the intersection of 'individual judgement and organizational forms appears to be particularly promising, and practically highly relevant give the demands of knowledge work' (Felin \& Spender, 2009). One key question is whether present activities in URCs foster an infrastructure conducive to extensive 'frame bending' (Brown \& Duguid, 1991) or whether centre directors and managers feel constrained by imposed canonical constraints or in their ability to access the levers necessary to directly affect the behaviours of individual researchers (Boardman \& Corley, 2004). Indeed, in light of their own career trajectories and employment contracts researchers themselves may be subject to insecurities which shape their research efforts. Evidently, adequate support will only come from an understanding of the details, sophistication and 
tension of actual practice (Whittington, 2007). The task of empirically advancing this research agenda is one that is currently being embraced.

\section{REFERENCES}

Adler, P. S. 2001. Market, hierarchy, and trust: The knowledge economy and the future of capitalism. Organization Science, 12(2): 215-234.

Adler, P. S., \& Heckscher, C. 2006. Towards collaborative community. In C. Heckscher, \& P. S. Adler (Eds.), The Firm as a Collaborative Community: Reconstructing Trust in the Knowledge Economy: 11-105. New York: Oxford University Press.

Adler, P. S., Kwon, S., \& Heckscher, C. 2008. Professional work: The emergence of collaborative community. Organization Science, 19(2): 359-376.

Ambos, T., Makela, K., Birkinshaw, J., \& D'Este, P. 2008. When does university research get commercialised? Creating ambidexterity in research institutions. Journal of Management Studies, 45(8): 1424-1447.

Appley, D. G., \& Winder, A. E. 1977. An evolving definition of collaboration and some implications for the world of work. The Journal of Applied Behavioral Science, 13(3): 279-291.

Argote, L., McEvily, B., \& Reagans, R. 2003. Managing knowledge in organizations: an integrative framework and review of emerging themes. Management Science, 49(4): 571-582.

Beaver, D. 2001. Reflections on scientific collaboration (and its study): Past, present, and future. Scientometrics, 52: 365-377.

Beaver, D., \& Rosen, R. 1978. Studies in scientific collaboration. Part I. Scientometrics, 1: 65-84.

Beaver, D., \& Rosen, R. 1979a. Studies in scientific collaboration. Part II. Scientometrics, 1: 133-149.

Beaver, D., \& Rosen, R. 1979b. Studies in scientific collaboration. Part III. Scientometrics, 1: 231-245.

Beesley, L. 2003. Science policy in changing times: Are governments posed to take full advantage of an institution in transition? Research Policy, 32: 1519-1532.

Beise, M., \& Stahl, H. 1999. Public research and industrial innovations in Germany. Research Policy, 28: 397-422.

Blomqvist, K., \& Levy, J. 2006. Collaboration capability - a focal concept in knowledge creation and collaborative innovation in networks. International Journal of Management Concepts and Philosophy, 2(1): 31-48.

Boardman, P., \& Corley, E. 2008. University research centres and the composition of research collaborations. Research Policy, 37(5): 900-913.

Bozeman, B., \& Boardman, P. C. 2003. Managing the New Multipurpose, Multidiscipline University Research Centers: Institutional Innovation in the

THE LEARNING, INNOVATION AND KNOWLEDGE (LINK) RESEARCH CENTRE WORKING PAPER SERIES WP 02-09

http://www.link.dcu.ie/publications/workingpaperseries/

(c) 2009, LInK, Angelos Alexopoulos, Brian Harney, Kathy Monks, Finian Buckley and Teresa Hogan

Contact: angelos.alexopoulos@dcu.ie 
Academic Community. Washington DC: IBM Center for the Business of Government.

Bozeman, B., \& Corley, E. 2004. Scientists' collaboration strategies: Implications for scientific and technical human capital. Research Policy, 33: 599-616.

Bozeman, B., Dietz, J., \& Gaughan, M. 2001. Scientific and technical human capital: An alternative model for research evaluation. International Journal of Technology Management, 22(7/8): 636-655.

Brint, S. 2005. Creating the Future: 'New Directions' in American Reserach Universities. Minerva, 43: 23-50.

Brown, J. S., \& Duguid, P. 1991. Organizational learning and communities-ofpractice: Toward a unified theory of working, learning, and innovation. Organization Science, 2(1): 40-57.

Brown, J. S., \& Duguid, P. 2001. Knowledge and organization: A social-practice perspective. Organization Science, 12(2): 198-213.

Ciborra, C. U. 1996. Teams, Markets and Systems (2nd ed.). Cambridge: Cambridge University Press.

Cohen, L., Duberley, J., \& McAuley, J. 1999. Fuelling discovery or monitoring productivity: Research scientists' changing perceptions of management. Organization, 6(3): 473-497.

Coleman, J. S. 1986. Social theory, social research, and a theory of action. American Journal of Sociology, 91: 1309-1335.

Crane, D. 1970. The nature of scientific communication and influence. International Social Science Journal, 22: 28-41.

Cronin, B. 1995. The Scholar's Courtesy: The Role of Acknowledgement in the Primary Communication Process. London: Taylor Graham.

DETE. 2006. Strategy for Science, Technology and Innovation. Dublin: Department of Enterprise, Trade and Employment (DETE).

DiMaggio, P. 1992. Nadel's paradox revisited: Relational and cultural aspects of organizational structure. In N. Nohria, \& R. G. Eccles (Eds.), Networks and Organizations: Structure, Form and Action: 118-142. Boston, MA: Harvard Business School Press.

Eaton, J. W. 1951. Social processes of professional teamwork. American Sociological Review, 16: 707-713.

Edge, D. 1979. Quantitative measures of communication in science: A critical review. History of Science, 17: 102-134.

Etzkowitz, H. 2003. Research groups as 'quasi-firms': The invention of the entrepreneurial university. Research Policy, 32: 109-121.

Etzkowitz, H., \& Leydesdorff, L. (Eds.). 1997. Universities in the Global Economy: A Triple Helix of University-Industry-Government Relations. London: Cassell Academic.

THE LEARNING, INNOVATION AND KNOWLEDGE (LINK) RESEARCH CENTRE WORKING PAPER SERIES WP 02-09

http://www.link.dcu.ie/publications/workingpaperseries/

(c) 2009, LInK, Angelos Alexopoulos, Brian Harney, Kathy Monks, Finian Buckley and Teresa Hogan

Contact: angelos.alexopoulos@dcu.ie 
Etzkowitz, H. A., Webster, C., Gebhardt, B., \& Terra, R. C. 2000. The future of the university and the university of the future: Evolution of ivory tower to entrepreneurial paradigm. Research Policy, 29: 313-330.

Felin, T., \& Hesterly, W. S. 2007. The knowledge-based view, nested heterogeneity, and new value creation: Philosophical considerations on the locus of knowledge. Academy of Management Review, 32(1).

Felin, T., \& Spender, J. C. 2009. An exchange of ideas about knowledge governance: Seeking first principles and microfoundations. In N. Foss, \& M. Snejina (Eds.), Knowledge Governance: A Multi-Disciplinary Perspective: 247-271. Oxford: Oxford University Press.

Foss, N. J. 2007. The emerging knoweldge governance approach: challenges and characteristics. Organization, 14(1): 29-52.

Garvey, W. D., \& Griffith, B. C. 1972. Communication and information processing within scientific disciplines: Empirical findings for psychology. Information Storage and Retrieval, 8: 123-136.

Geiger, R. L. 1990. Organized research units: Their role in the development of university research. The Journal of Higher Education, 61: 1-19.

Ghoshal, S., \& Moran, P. 1996. Bad for practice: a critique of the transaction cost theory. Academy of Management Review, 21(1): 13-47.

Granovetter, M. S. 1985. Economic action and social structure: the problem of embeddedness. American Journal of Sociology, 91(3): 481-510.

Granovetter, M. S. 1992. Economic institutions as social constructions: A framework for analysis. Acta Sociologica, 35(1): 3-11.

Hagstrom, W. O. 1965. The Scientific Community. New York: Basic Books.

Hays, S. W. 1991. From adhocracy to order: Organizational design for higher education research and services. Research Management Review, 5: 1-17.

Heckscher, C., \& Adler, P. S. (Eds.). 2006. The Firm as a Collaborative Community: Reconstructing Trust in the Knowledge Economy. New York: Oxford University Press.

Hernes, G., \& Martin, M. 2000. Management of University-Industry Linkages. Paris: International Institute for Educational Planning.

Inagami, T., \& Whittaker, D. H. 2005. The New Community Firm: Employment, Governance and Management Reform in Japan. Cambridge: Cambridge University Press.

Kang, S.-C., Morris, S. S., \& Snell, S. A. 2007. Relational archetypes, organizational learning, and value creation: Extending the human resource architecture. Academy of Management Review, 32(1): 236-256.

Katz, J. S., \& Martin, B. R. 1997. What is research collaboration? Research Policy, 26: $1-18$.

Knorr Cetina, K. D. 1999. Epistemic Cultures: How the Sciences Make Knowledge. Cambridge MA: Harvard University Press.

THE LEARNING, INNOVATION AND KNOWLEDGE (LINK) RESEARCH CENTRE WORKING PAPER SERIES WP 02-09

http://www.link.dcu.ie/publications/workingpaperseries/

(c) 2009, LInK, Angelos Alexopoulos, Brian Harney, Kathy Monks, Finian Buckley and Teresa Hogan

Contact: angelos.alexopoulos@dcu.ie 
Kogut, B., \& Zander, U. 1992. Knowledge of the firm, combinative capabilities and the replication of technology. Organization Science, 3(3): 383-397.

Lee, S., \& Bozeman, B. 2005. The impact of research collaboration on scientific productivity. Social Studies of Science, 35(5): 673-702.

Maccoby, M. 2006. The self in transition: From bureaucratic to interactive social character. In C. Heckscher, \& P. S. Adler (Eds.), The Firm as a Collaborative Community: Reconstructing Trust in the Knowledge Economy: 157-176. New York: Oxford University Press.

Mansfield, E. 1991. Academic research and industrial innovation. Research Policy, 20: $1-12$.

Mansfield, E. 1998. Academic research and industrial innovation: An update of empirical findings. Research Policy, 26: 773-776.

March, J. G. 1991. Exploration and exploitation in organizational learning. Organization Science, 2: 71-87.

Markman, G., Siegel, D., \& Wright, M. 2008. Research and technology commercialisation. Journal of Management Studies, 45(8): 1401-1423.

McGrath, P. 2005. Thinking differently about knowledge-intensive firms: Insights from early medieval monasticism. Organization Science, 12(4): 549-566.

Miles, R. E., Snow, C. C., \& Miles, G. 2000. The future.org. Long Range Planning, 33: $300-321$.

Owen-Smith, J. 2003. From separate systems to a hybrid order: Accumulative advantage across public and private science at research one universities. Research Policy, 32: 1081-1104.

Price, D. J. 1963. Little Science, Big Science. New York: Columbia University Press.

Price, D. J., \& Beaver, D. 1966. Collaboration in an invisible college. American Psychologist, 21: 1011-1018.

Rogers, E. M., Hall, B. J., Hashimoto, M., Steffensen, M., Speakman, K. L., \& Timko, M. K. 1999. Technology transfer from university-based research centres: The university of New Mexico experience. The Journal of Higher Education, 70: 687-705.

Salter, A., \& Martin, B. R. 2001. The economic benefits of publicly funded basic research: A critical review. Research Policy, 30: 509-532.

Schumpeter, J. A. 1934[1962]. The Theory of Economic Development: An Inquiry into Profits, Capital, Credit, Interest and the Business Cycle. Cambridge MA: Harvard University Press.

Sousa, C. A. A., \& Hendriks, P. H. J. 2008. Connecting knowledge to management: The case of academic research. Organization Science, 15(6): 811-830.

Stahler, G. J., \& Tash, W. R. 1994. Centres and institutes in the research university: Issues, problems and prospects. The Journal of Higher Education, 65: 540554.

THE LEARNING, INNOVATION AND KNOWLEDGE (LINK) RESEARCH CENTRE WORKING PAPER SERIES WP 02-09

http://www.link.dcu.ie/publications/workingpaperseries/

(c) 2009, LInK, Angelos Alexopoulos, Brian Harney, Kathy Monks, Finian Buckley and Teresa Hogan

Contact: angelos.alexopoulos@dcu.ie 
Staples, D. S., Greenaway, K., \& McKeen, J. D. 2001. Opportunities for research about managing the knowledge-based enterprise. International Journal of Management Reviews, 3(1): 1-20.

Stern, S. 2004. Do scientists pay to be scientists? Management Science, 50: 835-853.

von Krogh, G. 2003. Knowledge sharing and the communal resource. In M. EasterbySmith, \& M. A. Lyles (Eds.), The Blackwell handbook of organizational learning and knowledge management: 372-392. Oxford: Blackwell.

von Krogh, G., Ichijo, K., \& Nonaka, I. 2001. Enabling Knowledge Creation : How to Unlock the Mystery of Tacit Knowledge and Release the Power of Innovation. Oxford Oxford University Press.

Whittington, R. 2007. Strategy practice and strategy process: Family differences and the sociological eye. Organization Studies, 28(10): 1575-1586.

Williamson, O. E. 1985. Economic Institutions of Capitalism. New York: Free Press. 
TABLES AND FIGURES

Table 1: Taxonomy of University Research Centres

\begin{tabular}{|c|c|c|c|c|}
\hline Research Unit Type & Horizontal Relations & External Relations & $\begin{array}{l}\text { Extra-Research } \\
\text { Activities }\end{array}$ & $\begin{array}{l}\text { Research Problem } \\
\text { Focus }\end{array}$ \\
\hline Academic Department & $\begin{array}{l}\text { Minimal, except for } \\
\text { those pertaining to } \\
\text { curriculum } \\
\text { Administration }\end{array}$ & $\begin{array}{l}\text { Simple and } \\
\text { decentralized }\end{array}$ & $\begin{array}{l}\text { Teaching, university } \\
\text { and professional } \\
\text { service }\end{array}$ & $\begin{array}{l}\text { Discipline-based, } \\
\text { provides consensus } \\
\text { for rewards system }\end{array}$ \\
\hline Simple URC & $\begin{array}{l}\text { Simple, sometimes no } \\
\text { significant ones other } \\
\text { than to department }\end{array}$ & $\begin{array}{l}\text { Simple, negotiated by } \\
\text { researchers interacting } \\
\text { with networks of other } \\
\text { academic researchers } \\
\text { and government } \\
\text { funding agencies }\end{array}$ & Few or none & $\begin{array}{l}\text { Based on narrow set } \\
\text { of problems, usually } \\
\text { established by } \\
\text { discipline-based } \\
\text { "normal science" }\end{array}$ \\
\hline Complex URC & $\begin{array}{l}\text { Simple, sometimes no } \\
\text { significant ones other } \\
\text { than to department }\end{array}$ & $\begin{array}{l}\text { Moderate complexity, } \\
\text { including not only } \\
\text { academic networks } \\
\text { but other knowledge } \\
\text { user types, especially } \\
\text { industry }\end{array}$ & $\begin{array}{l}\text { More extensive, } \\
\text { including an expanded } \\
\text { educational role, or } \\
\text { industrial outreach, } \\
\text { or brokering diverse } \\
\text { network members }\end{array}$ & $\begin{array}{l}\text { Mix of problem-driven } \\
\text { topics and topics set } \\
\text { by discipline or field } \\
\text { specialization demands }\end{array}$ \\
\hline $\begin{array}{l}\text { Multipurpose, } \\
\text { Multidisciplinary } \\
\text { URC }\end{array}$ & $\begin{array}{l}\text { Varies, usually very } \\
\text { complex, cutting across } \\
\text { many units }\end{array}$ & $\begin{array}{l}\text { Complex, often } \\
\text { including multiple } \\
\text { external industry, } \\
\text { government, and } \\
\text { university actors }\end{array}$ & $\begin{array}{l}\text { Multiple, often } \\
\text { including } \\
\text { educational role, } \\
\text { industrial interaction, } \\
\text { scientific and } \\
\text { professional } \\
\text { brokering, } \\
\text { community outreach }\end{array}$ & $\begin{array}{l}\text { Almost entirely } \\
\text { problem driven, not } \\
\text { tracking closely to } \\
\text { disciplines } \\
\text { and established } \\
\text { scientific and technical } \\
\text { specializations }\end{array}$ \\
\hline
\end{tabular}


Table 2: Three Principles of Social Organisation

\begin{tabular}{cccc}
\hline $\begin{array}{c}\text { Principles of Social } \\
\text { Organisation }\end{array}$ & Market & $\begin{array}{c}\text { Collaborative } \\
\text { Community }\end{array}$ & Hierarchy \\
\hline $\begin{array}{c}\text { Coordination } \\
\text { mechanism }\end{array}$ & Price & Trust & Authority \\
Primary benefits & Flexibility & $\begin{array}{c}\text { Generation and sharing } \\
\text { of knowledge }\end{array}$ & Control \\
$\begin{array}{c}\text { Implications for } \\
\text { Knowledge } \\
\text { dissemination }\end{array}$ & $\begin{array}{c}\text { Strong incentives for } \\
\text { knowledge creation but } \\
\text { under appropriability } \\
\text { regimes }\end{array}$ & $\begin{array}{c}\text { Infrastructure for the } \\
\text { creation and diffusion } \\
\text { of knowledge in a } \\
\text { socially optimal way }\end{array}$ & $\begin{array}{c}\text { Codified knowledge, } \\
\text { weak at knowledge } \\
\text { creation, } \\
\text { Difficulty handling } \\
\text { tacit knowledge }\end{array}$ \\
Fits tasks that are & Independent & Interdependent & $\begin{array}{c}\text { Dependent } \\
\text { Archetype }\end{array}$ \\
& Cource: Adapted from Adler \& Heckscher (2006: 16), Adler et al., (2008: 360$)$ \\
\hline
\end{tabular}

Table 3: KIFs and Monastic Communities: Some Shared Features

\begin{tabular}{ll}
\hline Teamworking & $\begin{array}{l}\text { Allows a level of specialization; enables, through collaboration, extensive } \\
\text { knowledge sharing and the development of a communal orientation }\end{array}$ \\
\hline Strategy & $\begin{array}{l}\text { Clear and unifying mission but with little sense of elaborate strategic } \\
\text { planning }\end{array}$ \\
\hline Organic growth & Leading to wide variations in the size of individual units \\
\hline Knowledge & $\begin{array}{l}\text { Relatively discrete body of knowledge but emphasize interpretation and } \\
\text { applied skills or expertise in terms of exploiting their core knowledge. } \\
\text { Knowledge sharing within the organisation and externally between the } \\
\text { organisation and its clients a core philosophy }\end{array}$ \\
& $\begin{array}{l}\text { Active concern with the repackaging, reinterpretation and reuse of others } \\
\text { knowledge as their own }\end{array}$ \\
\hline Normative control & $\begin{array}{l}\text { Fostering of high commitment, high levels of responsibility and autonomy } \\
\text { and as a means of enabling dispersed activity }\end{array}$ \\
\hline Identity & $\begin{array}{l}\text { Cultivation of a distinctive sense of identity, of being different, superior and } \\
\text { elitist } \\
\text { Mystique and ambiguity surrounding their work } \\
\text { Positioning as mediators or guardians of a new uncertain order through their } \\
\text { mediation between market institutions and firms and between competing } \\
\text { firms themselves. }\end{array}$ \\
\hline
\end{tabular}

Source: Adapted from McGrath (2005) 
Table 4: Motives for Collaboration: A Summary

1. Access to expertise

2. Access to equipment, facilities and resources

3. Improve access to funds

4. Obtain prestige or visibility; for professional advancement

5. Efficiency in use of time; to make progress more rapidly

6. Efficiency in use of labour; multiple hands and minds

7. Tackle "bigger" problems

8. Enhance productivity

9. Create a network ("invisible college")
10. Retool, learn new skills and techniques, usually to break into a new field, subfield or problem

11. Satisfy curiosity; stimulate intellectual interest

12. Share the excitement of an area with other people

13. Locate and correct flaws more efficiently; reduce errors and mistakes

14. Keep one more focused on research, because others are counting on one to do so

15. Reduce isolation ("lone wolf"); recharge one's energy and excitement

16. Educate a doctoral student, postdoctoral researcher or oneself

17. Advance knowledge and learning

18. For fun, amusement and pleasure

Source: Adapted from Beaver (2001: 373)

\section{Figure 1: In Search of Microfoundations of Collaborative Innovation in URCs}

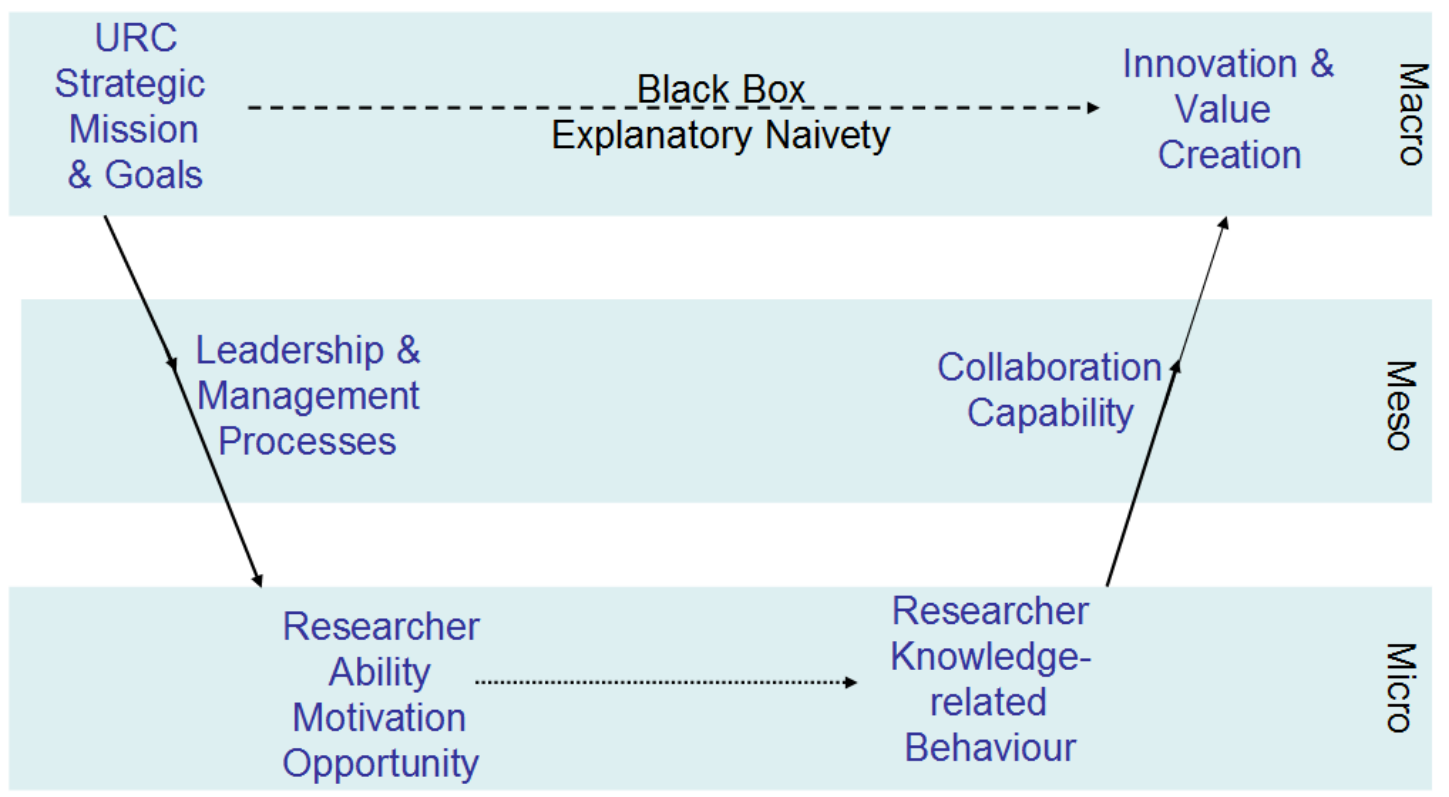

Drawing from Foss (2007) and Coleman (1986). 